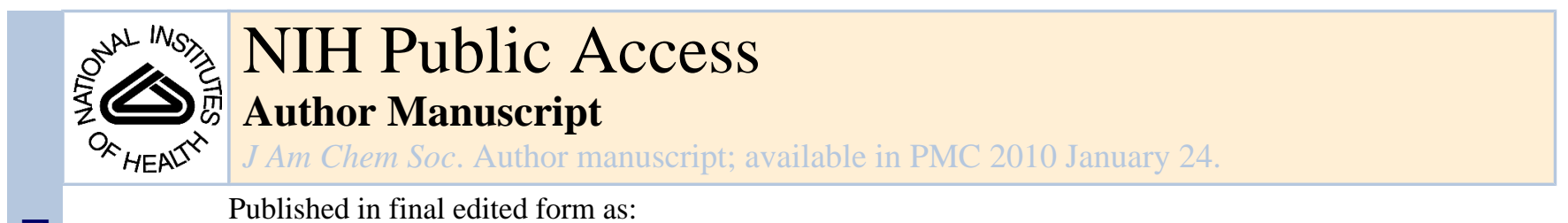

J Am Chem Soc. 2008 July 30; 130(30): 9638-9639. doi:10.1021/ja802355u.

\title{
A Targetable Fluorescent Probe for Imaging Hydrogen Peroxide in the Mitochondria of Living Cells
}

\author{
Bryan C. Dickinson and Christopher J. Chang* \\ Department of Chemistry, University of California, Berkeley, California 94720
}
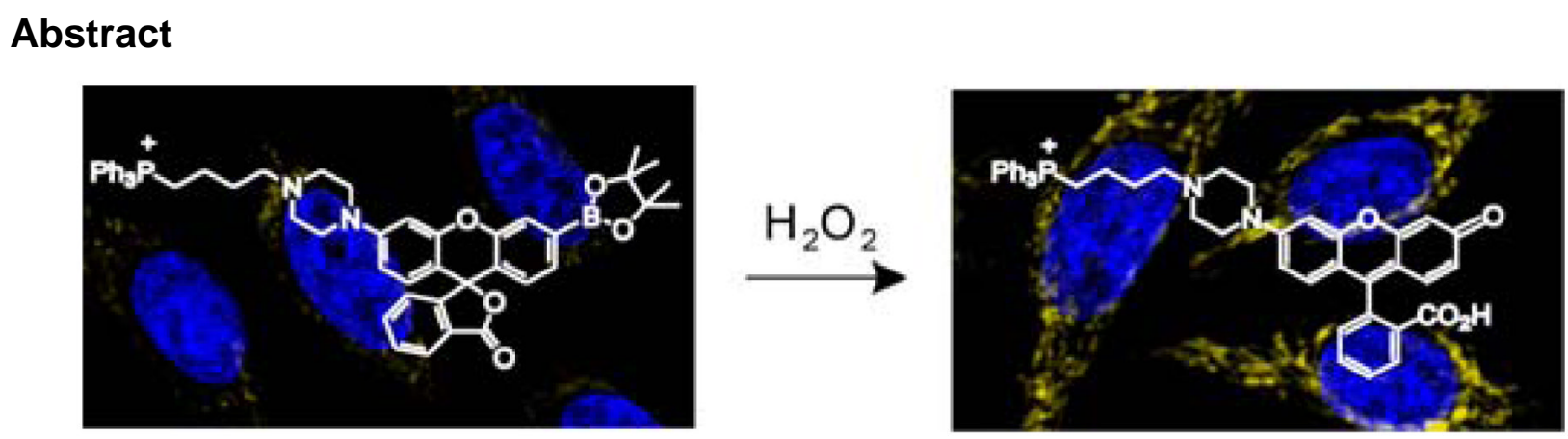

We present the design, synthesis, and biological applications of Mitochondria Peroxy Yellow 1 (MitoPY1), a new type of bifunctional fluorescent probe for imaging hydrogen peroxide levels within the mitochondria of living cells. MitoPY1 combines a chemoselective boronate-based switch and a mitochondrial-targeting phosphonium moiety for detection of hydrogen peroxide localized to cellular mitochondria. Confocal microscopy and flow cytometry experiments in a variety of mammalian cell types show that MitoPY1 can visualize localized changes in mitochondrial hydrogen peroxide concentrations generated by situations of oxidative stress.

Hydrogen peroxide $\left(\mathrm{H}_{2} \mathrm{O}_{2}\right)$ is an increasingly recognized small-molecule mediator of physiology, aging, and disease in living organisms. ${ }^{1-6}$ In this regard, aberrant production or accumulation of $\mathrm{H}_{2} \mathrm{O}_{2}$ within cellular mitochondria over time due to environmental stress(es) and/or genetic mutation(s) is connected to serious diseases where age is a risk factor, including cancer $^{7}$ and neurodegenerative Alzheimer's, Parkinson's, and Huntington's diseases. 8,9 Indeed, overexpression and mitochondrial targeting of catalase, a peroxide-detoxifying enzyme, can increase life span in mouse models. 10 On the other hand, newer data suggest that controlled bursts of mitochondrial $\mathrm{H}_{2} \mathrm{O}_{2}$ can also serve beneficial roles for cell survival, growth, differentiation, and maintenance. ${ }^{3-6}$

New imaging methods that allow visualization of localized production and accumulation of mitochondrial $\mathrm{H}_{2} \mathrm{O}_{2}$ in living samples are potentially useful for disentangling the complex contributions of this reactive oxygen species (ROS) to both healthy and diseased states. Synthetic fluorescent $\mathrm{H}_{2} \mathrm{O}_{2}$ indicators that can be targeted to precise subcellular locations offer one approach to this goal and do not require transfection like their protein counterparts, $11^{-}$ 12 but traditional ROS indicators such as dihydrorhodamine (DHR) are uncharged and hence not preferentially localized in cells before oxidation. ${ }^{13}$ In addition, DHR and related dyes are

chrischang@berkeley.edu.

Supporting Information Available: Synthetic and experimental details (PDF). This material is available free of charge via the Internet at http://pubs.acs.org 
not specific for $\mathrm{H}_{2} \mathrm{O}_{2}$ over other ROS. Accordingly, mitochondrial-targeted small molecules for detection of specific ROS remain rare ${ }^{13,14}$ and none of the probes reported to date are selective for $\mathrm{H}_{2} \mathrm{O}_{2}$. We now report the synthesis and applications of Mitochondria Peroxy Yellow 1 (MitoPY1), a new type of fluorophore for imaging mitochondrial $\mathrm{H}_{2} \mathrm{O}_{2}$ in living cells with ROS and spatial specificity.

Our overall strategy for fluorescence imaging of mitochondrial $\mathrm{H}_{2} \mathrm{O}_{2}$ in living systems is to create bifunctional dyes that contain both a peroxide-responsive element and a mitochondrialtargeting moiety. For the latter purpose, we were inspired by the use of phosphonium head groups by Murphy and others to deliver antioxidants, electrophiles, and EPR and optical probes to mitochondria, as these and related lipophilic cations selectively accumulate in this organelle due to proton gradient considerations. ${ }^{14-16}$ In addition, we sought a modular synthetic route that would allow facile introduction of a phosphonium or any other desired targeting group after installation of the boronate switch, which circumvents potential complications arising from sensitive functionalities that are incompatible with palladium-catalyzed Miyaura-Suzuki reactions typically used to introduce the $\mathrm{H}_{2} \mathrm{O}_{2}$-cleavable boronate cage. Both of these design criteria can be met by the approach outlined in Scheme 1 for the synthesis of MitoPY1. The ability to append additional groups post-boronation offers a host of opportunities for generating new multifunctional $\mathrm{H}_{2} \mathrm{O}_{2}$ imaging probes.

MitoPY1 features two major visible region absorptions $\left(\lambda_{\text {abs }}=489 \mathrm{~nm}, \varepsilon=14,300\right.$ $\left.\mathrm{M}^{-1} \mathrm{~cm}^{-1} ; 510 \mathrm{~nm}, \varepsilon=14,200 \mathrm{M}^{-1} \mathrm{~cm}^{-1}\right)$ and a weak emission $\left(\lambda_{\mathrm{em}}=540 \mathrm{~nm}, \Phi=0.019\right.$, Figure S1) in $20 \mathrm{mM}$ HEPES, pH 7. Reaction of MitoPY1 with $\mathrm{H}_{2} \mathrm{O}_{2}$ triggers a fluorescence increase by its conversion to MitoPY1ox, which possesses one major absorption band at 510 $\mathrm{nm}\left(\varepsilon=22,300 \mathrm{M}^{-1} \mathrm{~cm}^{-1}\right)$ and enhanced emission $\left(\lambda_{\mathrm{em}}=528 \mathrm{~nm}, \Phi=0.405\right)$. Kinetics measurements of the $\mathrm{H}_{2} \mathrm{O}_{2}$-mediated boronate deprotection were performed under pseudofirst-order conditions $\left(5 \mu \mathrm{M}\right.$ dye, $\left.10 \mathrm{mM} \mathrm{H}_{2} \mathrm{O}_{2}\right)$, giving an observed rate constant of $k=2.0$ $(1) \times 10^{-3} \mathrm{~s}^{-1}$. Figure 1 shows the relative turn-on fluorescence responses of MitoPY1 to a panel of biologically relevant ROS. Owing to its chemospecific boronate switch, ${ }^{17,18}$ the probe is selective for $\mathrm{H}_{2} \mathrm{O}_{2}$ over ROS like superoxide, nitric oxide, and hydroxyl radical.

MitoPY1 was then tested for its ability to both target the mitochondria and respond to $\mathrm{H}_{2} \mathrm{O}_{2}$ in living biological systems. Cervical cancer HeLa cells loaded with $5 \mu \mathrm{M}$ MitoPY 1 for $1 \mathrm{~h}$ at $37{ }^{\circ} \mathrm{C}$ show faint but measurable levels of fluorescence in discrete subcellular locations as determined by confocal microscopy (Figure 2a). Co-staining experiments with $50 \mathrm{nM}$ MitoTracker Deep Red, a commercially-available mitochondrial indicator (Figures 2b, 2c), or 500 nM LysoTracker Red, a lysosomal indicator (Figures S4-S7), establish that the observed fluorescence from MitoPY1 is localized to the mitochondria of these live cells. Addition of $100 \mu \mathrm{M} \mathrm{H}_{2} \mathrm{O}_{2}$ to HeLa cells loaded with MitoPY1 display a marked localized increase in fluorescence compared to control cells (Figure 2d-2f). Again, co-staining with MitoTracker confirms that the dye is retained in the mitochondria and detects localized rises in $\mathrm{H}_{2} \mathrm{O}_{2}$ concentrations. Brightfield measurements and nuclear staining with Hoechst 33342 indicate that the cells are viable throughout the imaging experiments (Figures 2b, 2e, $2 \mathrm{~g}$ ). In addition, control experiments using a probe lacking the phosphonium targeting moiety (ContPY1, Figure S9-S12) or the oxidized probe (MitoPY1ox, Figure S13-S18) confirm that only MitoPY1 targets the mitochondria, and complementary flow cytometry experiments (Figure S8) provide supporting data over a larger population of cells. Finally, analogous experiments in Cos-7, HEK293, and CHO.K1 cell lines give similar results and expand the scope of the probe (Figure S5-S7). Taken together, these data establish that MitoPY1 is targeted to cellular mitochondria, where it can respond to localized changes in $\mathrm{H}_{2} \mathrm{O}_{2}$ levels in living samples.

Finally, we sought to utilize MitoPY1 to visualize endogenous production of $\mathrm{H}_{2} \mathrm{O}_{2}$ in the mitochondria of living cells. To this end, we treated HeLa cells with paraquat, a small-molecule 
inducer of oxidative stress that produces Parkinson's-like phenotypes. ${ }^{19}$ The images in Figures $2 \mathrm{~h}-2 \mathrm{n}$ show clear increases in mitochondrial-localized $\mathrm{H}_{2} \mathrm{O}_{2}$ levels detected with MitoPY1 within cells that had been exposed to $1 \mathrm{mM}$ paraquat compared to control cells $\left(\mathrm{IC}_{50}\right.$ of paraquat in HeLa cells is $1.02 \mathrm{mM}){ }^{20}$ These data indicate that MitoPY1 is sensitive enough to detect local mitochondrial $\mathrm{H}_{2} \mathrm{O}_{2}$ elevations associated with oxidative stress in this Parkinson's model.

To close, we have presented the synthesis, properties, and biological applications of MitoPY1, a new targeted fluorescent probe that can selectively detect $\mathrm{H}_{2} \mathrm{O}_{2}$ in the mitochondria of living cells. Our data show that MitoPY1 is capable of imaging changes in the levels of $\mathrm{H}_{2} \mathrm{O}_{2}$ within the mitochondria of a variety of mammalian cell lines, as well as $\mathrm{H}_{2} \mathrm{O}_{2}$ elevations caused by an oxidative stress model of Parkinson's disease. In addition to applying MitoPY1 and related chemical tools for studies of mitochondrial redox biology, we anticipate that this modular probe scaffold should prove useful for creating new multifunctional probes for targeting, activation, and detection in living systems and are actively pursuing these possibilities.

\section{Supplementary Material}

Refer to Web version on PubMed Central for supplementary material.

\section{Acknowledgments}

We thank the Beckman, Packard, and Sloan Foundations, and the NIH (GM 79465) for providing funding for this work. B.C.D. thanks the NIH Chemical Biology Graduate Program (T32 GM066698) for support. We thank Holly Aaron (UCB Molecular Imaging Center) and Ann Fischer (UCB Tissue Culture Facility) for expert technical assistance.

\section{References}

1. Rhee SG. Science 2006;312:1882-1883. [PubMed: 16809515]

2. Stone JR, Yang S. Antioxid. Redox Signal 2006;8:243-270. [PubMed: 16677071]

3. Veal EA, Day AM, Morgan BA. Molecular Cell 2007;26:1-14. [PubMed: 17434122]

4. D'Autréaux B, Toledano MB. Nat. Rev. Mol. Cell Biol 2007;8:813-824. [PubMed: 17848967]

5. Giorgio M, Trinei M, Migliaccio E, Pelicci PG. Nat. Rev. Mol. Cell Biol 2007;8:722-728. [PubMed: 17700625]

6. Poole LB, Nelson KJ. Curr. Opin. Chem. Biol 2008;12:18-24. [PubMed: 18282483]

7. Finkel T, Serrano M, Blasco MA. Nature 2007;448:767-774. [PubMed: 17700693]

8. Barnham KJ, Masters CL, Bush AI. Nat. Rev. Drug Discovery 2004;3:205-214.

9. Lin MT, Beal MF. Nature 2006;443:787-795. [PubMed: 17051205]

10. Schriner SE, Jinford NJ, Martin GM, Treuting P, Ogburn CE, Emond M, Coskun PE, Ladiges W, Wolf N, Van Remmen H, Wallace DC, Rabinovitch PS. Science 2005;308:1909-1911. [PubMed: 15879174]

11. Belousov VV, Fradkov AF, Lukyanov KA, Staroverov DB, Shakhbazov KS, Terskikh AV, Lukyanov S. Nat. Methods 2006;3:281-286. [PubMed: 16554833]

12. Hanson GT, Aggeler R, Oglesbee D, Cannon M, Capaldi RA, Tsien RY, Remington S. J. Biol. Chem 2004;279:13044-13053. [PubMed: 14722062]

13. Koide Y, Urano Y, Kenmoku S, Kojima H, Nagano T. J. Am. Chem. Soc 2007;129:10324-10325. [PubMed: 17672465]

14. Robinson KM, Janes MS, Pehar M, Monette JS, Ross MF, Hagen TM, Murphy MP, Beckman JS. Proc. Nat. Acad. Sci 2006;103:15038-15043. [PubMed: 17015830]

15. Murphy MP, Smith RA. Annu. Rev. Pharmacol. Toxicol 2007;47:629-656. [PubMed: 17014364]

16. Hardy M, Chalier F, Ouari O, Finet J, Rockenbauer A, Kalyanaraman B, Tordo P. Chem. Commun 2007:1083-1085. 
17. Chang MCY, Pralle A, Isacoff EY, Chang CJ. J. Am. Chem. Soc 2004;126:15392-15393. [PubMed: 15563161]

18. Miller EW, Tulyathan O, Isacoff EY, Chang CJ. Nat. Chem. Biol 2007;3:263-267. [PubMed: 17401379]

19. McCormack AL, Thiruchelvam M, Manning-Bog AB, Thiffault C, Langtson JW, Cory-Clechta DA, Di Monte DA. Neurobiol. Dis 2002;10:119-127. [PubMed: 12127150]

20. Park SY, Choi J. Environ. Int 2007;33:817-822. [PubMed: 17499852] 


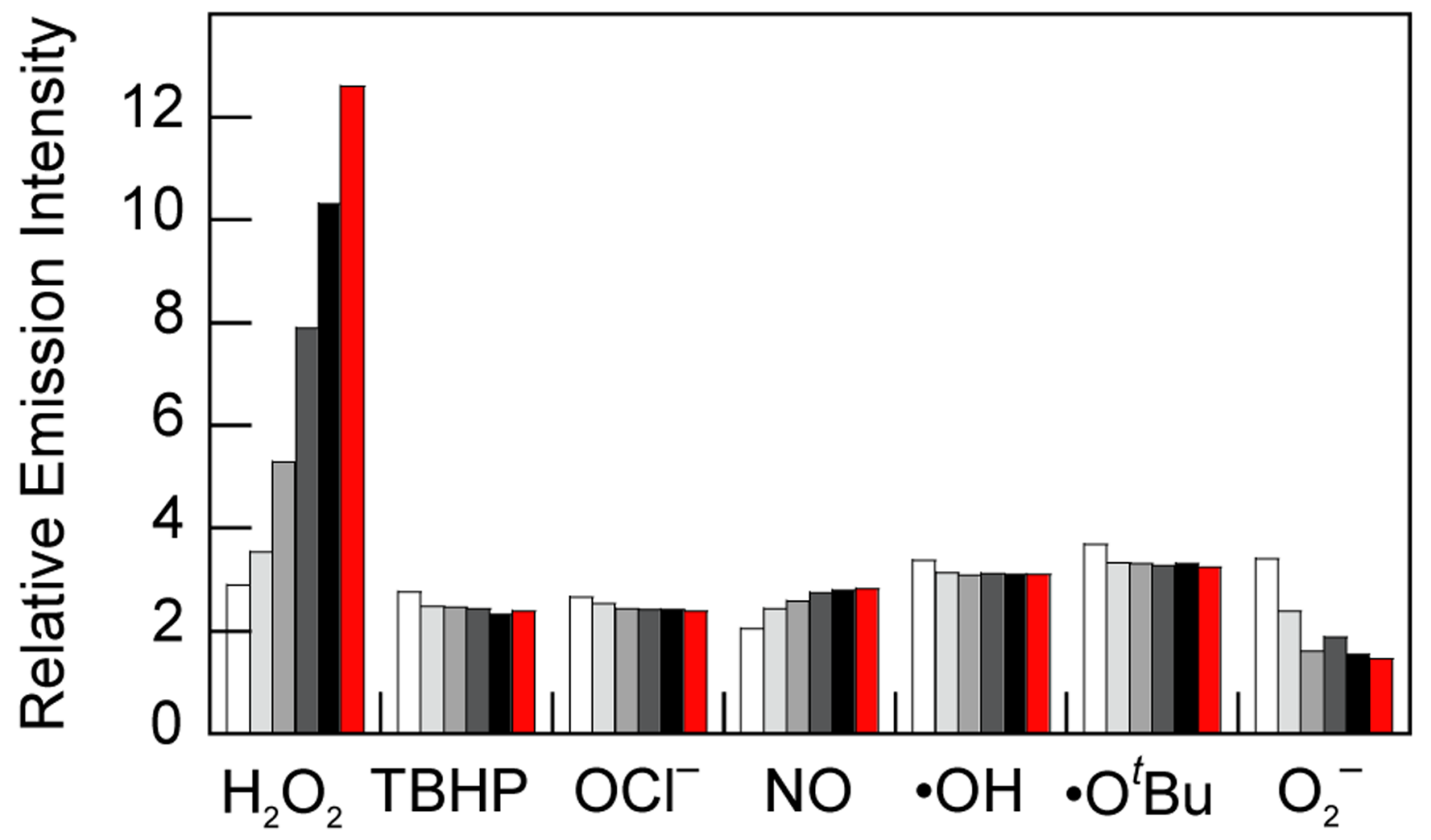

Figure 1.

Fluorescence responses of $5 \mu \mathrm{M}$ MitoPY1 to various reactive oxygen species (ROS). Bars represent relative responses at $0,5,15,30,45$, and 60 min after addition of each ROS. Data shown are for $10 \mathrm{mM} \mathrm{O}_{2}^{-}, 200 \mu \mathrm{M} \mathrm{NO}$, and $100 \mu \mathrm{M}$ for all other ROS. Data were acquired at $25^{\circ} \mathrm{C}$ in $20 \mathrm{mM}$ HEPES, $\mathrm{pH} 7$, with excitation $\lambda=503 \mathrm{~nm}$ and emission collected between 510 and $750 \mathrm{~nm}$. 

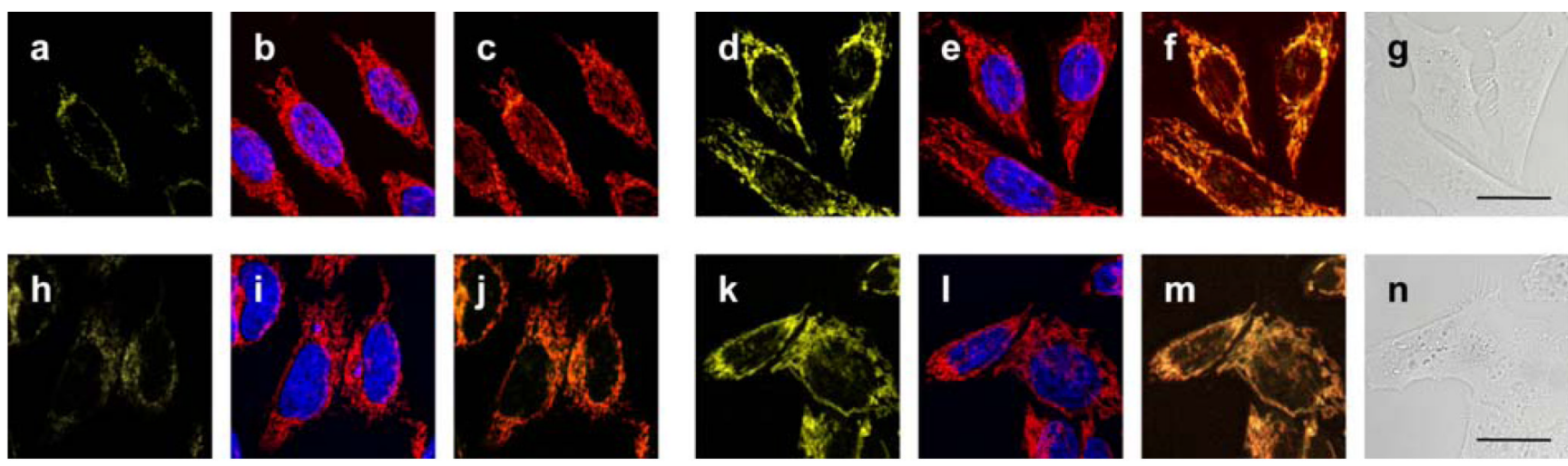

n

Figure 2.

Confocal fluorescence images of live HeLa cells with increases in mitochondrial $\mathrm{H}_{2} \mathrm{O}_{2}$ levels visualized using MitoPY1. Images displayed represent emission intensities collected in optical windows between 527-601 nm upon excitation at $510 \mathrm{~nm}$ for MitoPY1. HeLa cells incubated with $5 \mu \mathrm{M}$ MitoPY1 for $60 \mathrm{~min}$ at $37^{\circ} \mathrm{C}$ and imaged with MitoPY1 (a), MitoTracker Red and Hoechst (overlay, b), and MitoPY1 with MitoTracker Red (overlay, c). HeLa cells incubated with $5 \mu \mathrm{M}$ MitoPY 1 for $60 \mathrm{~min}$ at $37^{\circ} \mathrm{C}$ with $100 \mu \mathrm{M} \mathrm{H}_{2} \mathrm{O}_{2}$ added for the final $40 \mathrm{~min}$ and imaged with MitoPY1 (d), MitoTracker Red and Hoechst (overlay, e), MitoPY1 and MitoTracker Red (overlay, f), and brightfield (g) with $20 \mu \mathrm{m}$ scale bar. HeLa cells incubated with $5 \mu \mathrm{M}$ MitoPY1 for $60 \mathrm{~min}$ at $37^{\circ} \mathrm{C}$ and imaged with MitoPY1 (h), MitoTracker Red and Hoechst (overlay, i), and MitoPY1 with MitoTracker Red (overlay, j). HeLa cells incubated for $24 \mathrm{~h}$ with $1 \mathrm{mM}$ paraquat, then washed and incubated with $5 \mu \mathrm{M}$ MitoPY1 for $60 \mathrm{~min}$ at $37^{\circ} \mathrm{C}$ and imaged with MitoPY1 (k), MitoTracker Red and Hoechst (overlay, l), MitoPY1 and MitoTracker Red (overlay, m), and brightfield (n) with $20 \mu \mathrm{m}$ scale bar. 
<smiles>O=C(O)c1ccccc1C(=O)c1ccccc1C(=O)O</smiles><smiles>O=C1OC2(c3ccc(O)cc3Oc3cc(N4CCN(C(F)F)CC4)ccc32)c2ccccc21</smiles>

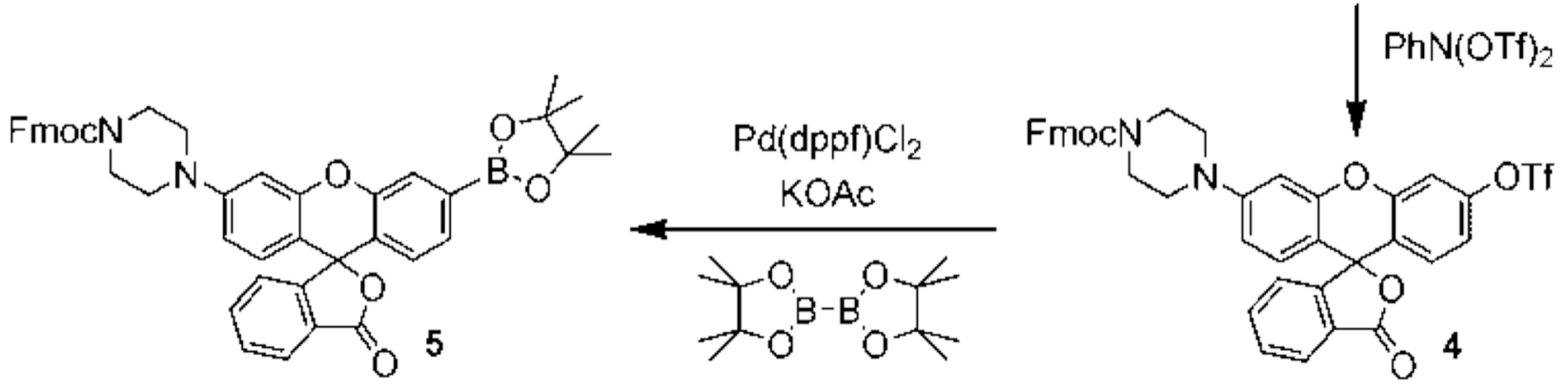

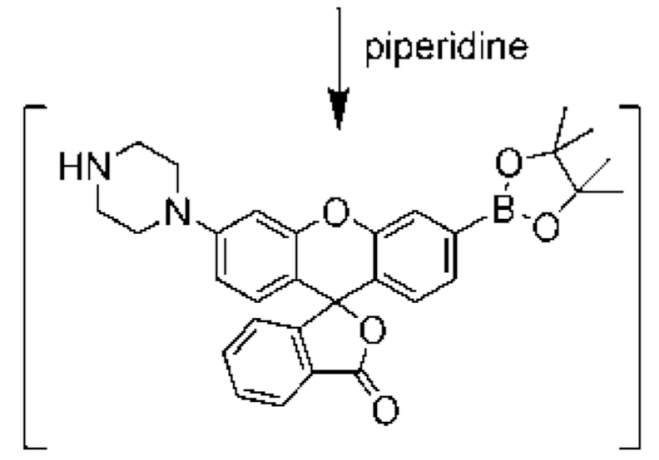

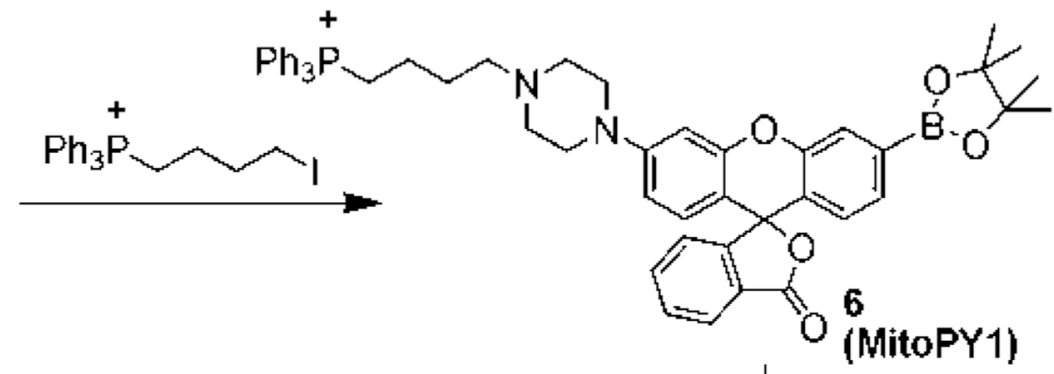

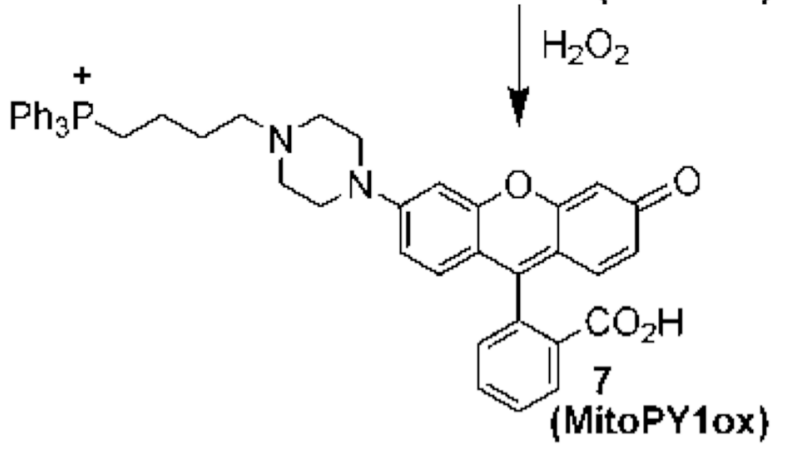

Scheme 1.

Synthesis and Activation of MitoPY1 